\title{
THE STRUCTURAL PERFORMANCE OF HOUSES IN EARTHQUAKES R.C. Cooney*
}

\section{SYNOPSIS}

The paper discusses the structural performance of New Zéaland houses in past earthquakes, the development of building regulations for timber construction in New Zealand and the consequent development in construction; and the earthquake resistance of contemporary timber construction.

\section{INTRODUCTION}

Houses in New Zealand have been infrequently subjected to severe earthquakes and because of this and the fact that the loss of life due to failure of house structures has been small, the performance of houses in earthquake has seldom been considered when changes in construction have occurred. However three recent events have prompted an examination of this aspect of light timber frame construction.

1. In 1968 an earthquake severely damaged a number of houses in the Inangahua area of New Zealand to the extent that many were uninhabitable immediately after the earthquake and the majority of houses required significant repairs.

2. The 1971 San Fernando earthquake in California, United States of America, severely damaged a large number of houses and prompted an examination of their design, particularly those other than single storey. This resulted in a detailed design manual being developed for some types of houses (with the result that the design process for these houses has become more involved).

3. In 1972 the Standards Association of New Zealand initiated a revision of the New Zealand standard for light timber frame building construction. As part of this work the performance of these structures in earthquakes was studied and some changes to construction were proposed. The new standard was published in November 1978 and it is expected to be adopted by approving authorities during 1979

In recent years there have been technological advancements which have resulted in a rapid growth in the range of materials and products available for house construction. This means that timber frame houses currently being constructed in New Zealand possess structural performance characteristics different from those buildings which were being built when the previous building bylaws were written, and whose performance was approximately established at that time.

Additionally, the complex manner in which

* Structural Research Engineer, Building Research Association of N.Z. (The opinions expressed in this paper are those of the author and are not necessarily those of the Building Research Association of N.Z.) the various elements of a house interact to give the total structural performance has required an engineering investigation in order that the replacement of individual elements by a new form of construction will still give the required performance.

\section{HOUSES AND EARTHQUAKES: THE PAST}

The first major earthquake to test timber frame houses occurred on 16 October 1848 near Wellington. Most of the houses of the 4,800 European inhabitants of Wellington were constructed of masonry although a significant number were similar to timber frame European houses of that time.

After this experience the majority of houses were rebuilt in timber. On 23 January 1855 Wellington, now with a European population of 6,400 , was again shaken by a severe earthquake. Reports indicate that $80 \%$ of chimneys were felled and that many masonry houses were damaged or destroyed. However, damage to the wooden houses was relatively slight. Outside Wellington many houses in the Wairarapa and in the north of the South Island were severely damaged or destroyed.

On 17 June 1929 the next major earthquake occurred in the Buller region, and Grayland (1) reported severe damage to houses in the town of Murchison.

New Zealand's greatest earthquake disaster occurred on 3 February 1931 at Napier, and Dixon(2) reported :

"Happily, little, if any, loss of life was attributable in the recent disaster to the collapse of wooden buildings... As a structure, the wooden framed building or light building has proved to have an exceedingly high earthquake resistance. Well over $90 \%$ suffered no other damage than that resulting from falling chimneys... Amongst the few cases of failure, however, is sufficient evidence to disclose the relative importance of the various weaknesses of design and construction. In their order of importance they are as follows:

(1) Lack of anchorage of the superstructure to the foundations, allowing the superstructure to slide off the foundations.

(2) Lack of bracing of subfloor framing or 
jack-studding.

(3) Inefficient bracing of wall panels, allowing racking of the lower storey in buildings of two or more storeys."

Similar observations were made by Brodie et al (3).

On 24 June 1942 a severe earthquake struck the Wairarapa region and was also strongly felt in Wellington where it is reported that 5,000 houses were damaged and over 10,000 chimneys demolished. On 2 August 1942 a severe after-shock ocuurred and Grayland $(1)$ notes that in Wellington considerably greater than 12,000 chimneys were damaged. In both earthquakes it was reported that houses were damaged over much of the lower part of the North Island.

In succeeding years a number of moderate earthquakes damaged houses in Gisborne and Seddon and as an example, Adams et al (4) reported of the performance of residential construction in the Seddon earthquake of April 1966:

"lack of bracing to heavy roofs and veneer walls, incomplete concrete foundations, unreinforced or partly reinforced chimneys, inadequate ties to veneers, large and unsymmetrical window or other openings, and irregular plan shape tend to bring damage to houses".

On 24 May 1968 a severe earthquake struck the small township of Inangahua and surrounding district, and whilst only 50 houses in that town and 30 on adjacent farmland were affected by the most severe shaking, they were of varying constructions both old and new and provide an indication of the structural performance of some more recent house constructions in earthquakes. The types of house constructions and the damage to these houses is reported by Shepherd et al $(5)$.

This concludes a brief account of the major damage to houses in New Zealand resulting from past earthquakes. It is also worth noting the severe damage suffered by some houses in the San Fernando earthquake of 9 February 1971 and reported by Housner et al (6) since these were of similar construction to many houses in New Zealand. The houses concerned were of two storey and split-level construction with garaging being provided in the lower storey of the two-storey portion. Racking failures occurred in these lower storeys.

The reported accounts illustrate that the following significant failings in house constructions have persistently reoccurred.

(a) Inadequate lateral support between ground floor level and the ground, particularly where piles or timber stud framing is used.

(b) Inadequate racking resistance in lower storey walls, particularly when concrete or clay tile roofs are used.

(c) Inadequate bracing of roof framing when concrete or clay tiles are used and inadequate fixing of these tiles.

(d) Inadequate strength of chimneys.

Failings (a), (b) and (c) represent the greatest loss in terms of reinstatement costs and disruption to the lives of the house occupiers whilst (c) and (d) represent the greatest risk to life and limb.

\section{REGULATIONS AND HOUSES}

\section{Early Days}

In the 19th and earlier 20 th centuries timber frame house construction essentially evolved in line with experience and established trade practice and there is little evidence to suggest that regulations affected the method of construction. From the beginning of the 20th century some local bodies did have building bylaws for houses but these did not deal with structural matters.

In 1924, a conference of representatives of local bodies, architects, engineers, builders, timber merchants and saw millers produced recommendations entitled "Recommended Minimum Requirements for Safe and Economical Construction of Small Wooden Frame Buildings". These were designed to apply to shops, offices and houses of up to 3 storeys in height. These recommendations were published $(7)^{\circ}$ and were generally adopted since they represented what was considered to be good construction practice.

Whilst these recommendations mention specific provisions for earthquakes such provision was more apparent than real. In the subfloor area, houses could be supported on free standing foundation blocks (piles) having a height of up to $1.2 \mathrm{~m}$ above finished grade level without any form of bracing. Of timber stud subfloor walls the recommendations required that, jack-studs in basements shall be not less than 4" $\times$ 3" and where they are of greater length than 4 feet they shall be securely braced, and this is the only mention of bracing in the subfloor area. It can only be assumed that since the last severe earthquake occurred in 1855, that any lessons learnt from that event had been substantially lost with time. It is also apparent that in 1955, buildings were built predominantly on a level building site with short stubby building blocks which offered reasonable resistance to over-turning. Buildings on taller blocks, (providing greater subfloor ventilation and also catering for sloping ground) may not have been tested by an earthquake before 1924 .

On wall bracing the recommendations suggested that "All corners of external walls shall be diagonally braced, and such other measures taken to secure rigidity as may be necessary, either by braces not less than $3^{\prime \prime} x$ liz" or by battens not less than 4" $x$ l" checked flush with the outside surface of the studs and into all plates. Where sheathing is laid diagonally the bracing may be omitted".

The only other points of significance in these recommendations are contained in the conferenceconclusions which state; "wooden houses of 3 storeys and less in height and those roofed with light materials offer a fairly high resistance to shock...... In tile roofs every tile should be individually secured so that it cannot slip during an earthquake." 
1929 Dixon (2) prepared an article discussing and making recommendations for the design and construction of light wooden buildings to resist earthquakes, tornadoes and fires. This article was in fact published shortly after the Napier earthquake of 1931, however it required very little amendment as a result of that event. These recommendations for earthquake resistant construction of timber framed houses are the most comprehensive of any produced in this country and it is indeed unfortunate that many of these were omitted from building bylaws, and those that were included have in many cases not been adhered to from that time to the present day.

The specific recommendations of Dixon are too lengthy to quote here, suffice to say that the latest N.Z. standard NZS 3604(8) now provides for most of his recommendations, particularly in the areas of subfloor bracing, wall bracing and roof framing bracing.

\section{The First Codes}

The sequence of events following the Napier earthquake which led to the first national standard for the construction of light timber frame houses is best described by quoting from ten Broeke(9):

"Following the disastrous Hawke's Bay earthquake in 1931, the Government set up a building regulations committee to investigate the whole question of earthquake resistant design and construction. As the committee concluded the earthquake demonstrated the need for more adequate building bylaws, it was asked by the Government to draft a model building bylaw. The Standards Institution, which had come into existence in the meantime, was asked in 1934 to complete this bylaw, and the building bylaws committee was set up to proceed with this work. The committee completed the original model bylaw in 1935 . This was published as NZS 95 and consisted of 10 sections in one single document......

In 1938 a conference of representatives of local authorities, Government departments and other major interests was called by the Minister of Industry and Commerce, to consider numerous representations from the local authorities asking for substantial revision and extension of the model building bylaw. The conference agreed on the need to expedite the standardisation of local authority bylaws, as the only effective means for the formulation and adaptation of adequate building bylaws throughout the country.

Revisions and extensions took place from time to time and in 1944 Part IX Light Timber Construction was published......."

Whilst there is no doubt that NZSS 95 contains a number of bracing provisions which result from experiences with the 1929 and 1931 earthquakes, close inspection reveals some inherent inadequacies and as previously mentioned, some of Dixon's specific recommendations for instance were not incorporated. It also appears that the damage which resulted from the 1942 Wairarapa earthquake, apart from that to chimneys, did not materially affect the provisions of that standard.

As far as piled foundations were concerned NZSS 95(10) permitted houses to be built on free standing piles which averaged up to $760 \mathrm{~mm}$ height above ground level without cantilever or moment restraint to the piles. If the piles were more than $760 \mathrm{~mm}$ above the ground a system of walings and braces to the piles was required, both under external walls and in pile rows at approximately $4.9 \mathrm{~m}$ centres in both directions. Unfortunately the method of fixing these braces was not specified, and indeed a method is not particularly obvious, and this together with other vague requirements, may well have been the reasons for the braces and walings being generally omitted from these construction in actual practice.

The construction of subfloor stud walls, including bracing, was required to be as for the storey immediately above, however such walls were generally only located under external walls with isolated jack-studs on piles used internally and hence the requirement for braces in walls at $6.1 \mathrm{~m}$ intervals in both directions could not be complied with and was apparently ignored resulting in inadequately braced subfloor framing.

In contrast to subfloor bracing, the requirements for the bracing of walls within storeys can be considered in many respects to have been quite adequate. It is interesting though to note that cut-between (or filler) braces were permitted since Dixon stated:

"The failure of jack-studding or subflooring frame work and of lower storeys due to lack of bracing raises the practical question of 'what constitutes adequate wall bracing?' The fact that in a number of walls, reinforced with the usual type of 'filler' or 'solid' brace, the bracing failed in both tension and compression, indicates that this method of strengthening the wall is of doubtful value".

and when discussing the results of bracing tests conducted at the USA Forest Products Laboratory he states:

"These results confirm several reforms and improvements in building construction which the state Forest Service has consistently advocated for several years, viz.: The substitution of "cut-in" or "checked-in" braces for the "filler" type at present so widely used. The evidence secured at Napier, supported by the Madison tests, appears to justify prohibition of the "filler" brace which, in addition, is more expensive to construct."

The bracing of roof framing was covered in NZSS $95(10)$ by the non-specific statement that; 'roof framing and trussing shall be thoroughly and effectively diagonally braced. In hip roofs of small span hips may, with the permission of the engineer, be used instead of braces'.

It is worth noting that the extra seismic loading which resulted from the use of heavy concrete or clay tiled roofs was not reflected in any extra subfloor, wall, or roof bracing requirements for buildings having such roofs. Since metal or fabric roof coverings were required to be laid on $25 \mathrm{~mm}$ thick sarking, the difference in mass between these roofs and tiled roofs may not have been considered to have been significant 
enough to warrant special details.

The 1935 NZS $95^{(11)}$ requirements included continuous reinforcement of chimney flues above the gathering and $25.4 \mathrm{~mm}$ thick boarding in roofs around the chimney. This was superceded by Part XII Chimneys of NZSS 95 (10) in 1951 which considerably extended the requirements and included a requirement for chimneys to be:

"(i) Secured to the building at the ceiling, the roof line and at each floor level; or

(ii) Designed to be self-supporting."

A subsequent amendment in 1959 deleted the surrounding boarding requirement.

The specifications for the construction of state owned houses had a significant effect on house construction in general and NZSS 95 (10). The 1936 State Housing specification required continuous reinforced concrete foundation walls around the perimeter of the houses and whilst this was required as a precaution against termite infestation and for use in Auckland's expansive clays, this was extremely good practice for earthquake resistance. The 1939 specification required continuous concrete foundation walls, $150 \mathrm{x}$ $25 \mathrm{~mm}$ let-in braces for wall framing (previously usually $100 \times 25 \mathrm{~mm})$, every roof tile to be wired and the bottom two courses to be wired and nailed, roof strutting, and chimneys to be reinforced. This specification appears to have been the best prepared in those years so far as earthquake provisions are concerned. However since many fixings were not specifically detailed this specification still required that the construction be of good trade practice.

The 1946 State housing specification bears strong resemblance to NZSS $95(10)$ and this is to be expected, however in terms of the earthquake performance this specification was in part a step backward from the 1939 state housing specification. Piles were reintroduced under the perimeter walls and one reason for this was the decreased risk of termite infestation. This resulted in the most significant reduction in earthquake performance of such houses. Wall bracing was essentially as per NZSS 95 (10) having been reduced from the previous requirement of a $150 \times 25 \mathrm{~mm}$ brace in every wall panel. Only alternate roofing tiles were required to be wired resulting in increased risk of damage and injury from dislodged tiles.

\section{Codes Revised:}

NZSS $95^{(10)}$ remained essentially unchanged until 1964 when the system of building bylaws was altered and it was superceded by NZSS $1900^{(12)}$. Some slight amendments were made at this time, but these were minimal and the requirements were virtually unchanged. Two unusual exceptions were: the bracing of roof framing or trusses was no longer required, and whereas NZSS $95(10)$ had permitted outer walings to piles to be omitted if baseboards were used (implying the outer of the two walings in external pile rows only) NZSS 1900 (12) deleted the word "outer" and this, as previously mentioned, had been literally taken in practice to mean all walings. One unusual exception was that the requirement for the bracing of roof framing or trusses which had been previously required by NZSS 95 (10) was deleted. The only other relevant change was the provision that if $12.7 \mathrm{~mm}$ thick plywood covered the studs then other bracing could be omitted. With a trend in recent years to large landscape windows and hence smaller wall sections, this relatively simple provision is no longer adequate. (Fig. 1.)

\section{A Modern Code}

By the early 1970's the number of significant innovations in the method of construction of houses had increased substantially and NZSS 1900 Chapter 6.I (12) was no longer relevant in so many areas that a major updating was required. During the initial stages of this updating it became apparent that a standard based essentially on the previous one was no longer relevant. It was no longer possible to rely on good trade practice, based on experience gained in previous earthquakes, since such earthquakes infrequently occurred in the more populated areas. (The Inangahua earthquake of 1968 did not have any significant effect on construction practices on a national scale.) Hence the completely new standard NZS 3604 (8) was prepared and published late in 1978 and it is expected to be adopted by most local authorities during 1979. This standard bears little resemblance to its predecessors and represents a major advance in the specification for improved earthquake performance of light timber frame houses.

As far as earthquake forces are concerned NZS $3604(8)$ recognises for the first time the three differing regions of seismicity in New Zealand as given by the general loading standard NZS $4203(13)$. Two ranges of roof mass are provided for; typically light sheet metal and heavy concrete tile; and this is reflected in differing provisions for roof bracing, wall bracing and sub-ground floor bracing. Likewise 1, 2 or 3 storey buildings are similarly treated with respect to wall and subfloor bracing requirements. A number of different types of foundation and subfloor framing systems are offered as are a number of wall bracing systems.

Structural diaphragms of sheet materials for floors, ceilings and roofs are detailed. At the same time sufficient flexibility of plan arrangement for walls has been provided in order to limit the number of instances when specific engineering design is required. Specific fixing details are given for all structural joints in the structure, be they bolted, nailed or by proprietary fixing.

Whilst it is recognised that in general the traditional timber frame house, heavy tiles and chimneys aside, presents relatively slight risk to life or limb, this new standard is aimed at minimising the damage to houses in major earthquakes and ensuring that they are essentially habitable after such an event.

It is perhaps significant that these substantial changes in regulations have occurred at a time other than immediately following an earthquake disaster and in fact when virtually no contemporary house construction have been subjected to a severe earthquake. In this manner, hopefully the tendence to over-react after a disaster, as so often happens, will be averted. Perhaps it could 
be said that the N.Z, code writers have taken the advice of Yanev $(14)$ who said after the 1971 San Fernando earthquake:

"The same types of buildings that failed in 1906 also failed in 1933 in Long Beach, in 1952 in Bakersfield, in 1964 in Alaska and in 1971 in San Fernando. The same types of buildings will continue to fail until building codes, builders and property owners pay some heed to history and the principals of physics and earthquake engineering."

\section{HOUSE CONSTRUCTIONS}

\section{General}

Light timber frame house construction, while apparently similar in their constructions over many past decades, have in fact been subjected to a number of significant changes which affect their performance in an earthquake. Such changes have generally been brought about by improvements in the materials and components used. Significant regional differences in construction also appear to exist.

\section{Foundations}

Early foundations consisted solely of timber piles or stone blocks without any form of lateral support provided by bracing, or cantilever action through embedment in the ground. In due course such piles or blocks were replaced by equivalent concrete piles.

Apart from chimneys, no other single element of construction has resulted in as many failures in earthquakes as have piles (Figs. 2 and 3 ). It is worth noting however that by far the most common foundation construction that has been subjected to severe earthquakes in NZ has been the piled foundation which directly supports the bearers supporting the ground floor joists. The poor performance of these constructions in past earthquakes is reported by the N.Z. Institute of Architects(15), Milne(16) and Shepherd et al (5).

Whilst not all houses on piles suffered failure this was probably because of other factors such as differing ground motions at differing sites and in different earthquakes, and the relatively flexible pile construction having a reduced response to the particular ground motion.

One aspect of piled foundations is however significant. Because of the flexibility and hence reduced response, the inertia forces in the superstructure would have been less than had these buildings been more rigidly connected to the ground and thus the damage to walls and roofs would have been less. In addition, the shear loads able to be imposed on a superstructure are effectively limited by the shear strength of the piled system. These facts must be borne in mind when considering damage in superstructures of such houses in previous earthquakes.

NZS $3604^{(8)}$ permits a total piled foundation for single storey houses only, however such piles must be either diagonally braced or, for internal piles only, may be cantilevered from a substantial footing. Such lateral support is required in external pile rows and internal rows at maximum $5 \mathrm{~m}$ spacing.

Both NZSS $95^{(10)}$ and NZSS $1900^{(12)}$ required that where the bottom plate of the ground floor wall framing was more than $1.2 \mathrm{~m}$ above ground level, corner foundation walls extending at least $1.37 \mathrm{~m}$ along each external wall were required and where walings connected to external piles were provided such walings were also to be connected to these corner walls. In practice such walings were not provided let alone connected to the walls, however such walls did offer greater lateral support than piles alone and such a foundation system has been used to a significant extent in state housing. The performance of such a foundation system was noted by Hamilton et al (17) in the moderate Gisborne earthquake of 1966 .

Continuous concrete foundations have generally always been used for three storey buildings and were also introduced for lesser storeyed buildings as a measure against termite infestation. It does not appear that their mandatory introduction to state housing was connected with improved performance in earthquakes, even though their earthquake resistant properties were noted by the NZ Institute of Architects (15) and Shepherd et al(5) following the Murchison and Inangahua earthquakes.

NZS 3604 requires continuous perimeter foundation walls of reinforced masonry or concrete for 2 and 3 storey houses. For 2 storey houses the foundation must extend up to the ground floor level for at least $40 \%$ of the perimeter while for 3 storey houses it must extend up to the ground floor level around the entire perimeter.

One weakness in the previous regulations was that the timber wall plate on top of the foundation walls needed only to be fixed to the foundation with $4 \mathrm{~mm}$ diameter galvanised wire; the wire being embedded in the wall and stapled to the plate. In most areas the alternative method of fixing using $10 \mathrm{~mm}$ dowels or bolts has generally been used, although the inferior wiring alternative was very common in some South Island areas, particularly Christchurch, where it is still used today. This wiring alternative is no longer provided for in NzS $3604(8)$.

By far the most satisfactory foundation is the concrete slab-on-ground which has been increasingly used in recent years. In an earthquake ground floor essentially moves with the ground motion, the response of the superstructure is likely to be greater than on any other type of foundation. In the Inangahua earthquake only one house of this construction existed; this house being quite conventional and having a corrugated iron roof and weatherboard exterior cladding. The damage to interior wall finishes, and the fact that a floor scatter rug was found firmly wedged beneath an external wall plate and the concrete floor, suggest that the superstructure of the house had been subjected to relatively large forces and had suffered large racking displacements(18).

Sub Floor Framing

When houses are constructed on sloping 


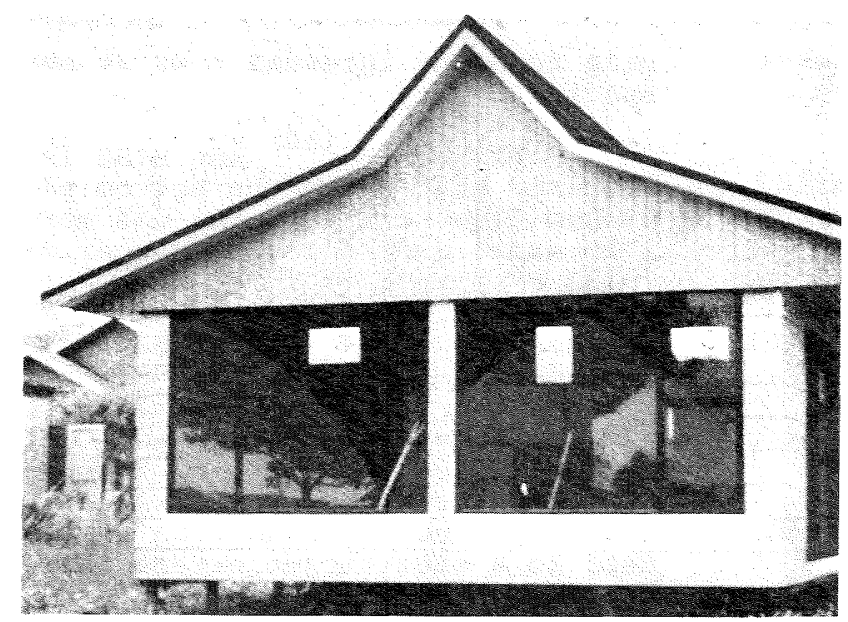

FIG 1 : Unchecked trend to landscape windows means that the effective bracing of a wall is often not possible

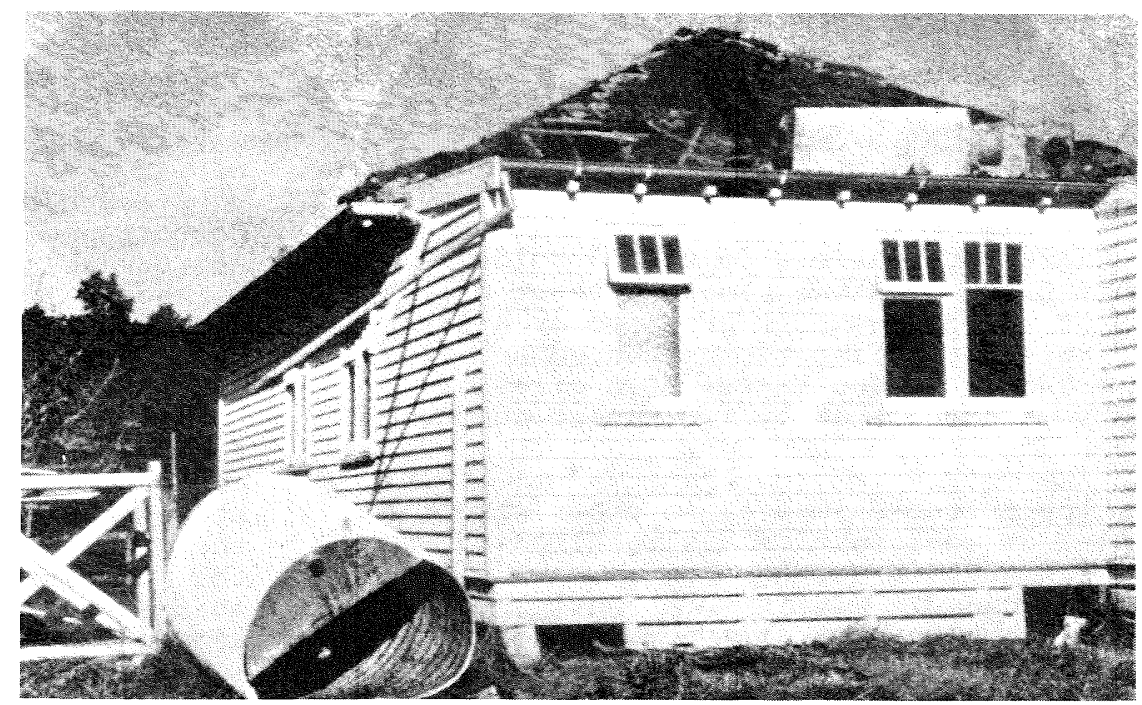

FIG 2: Inangahua earthquake: Lateral displacement of piles, damage to concrete tiled roof and chimney and loss of water supply

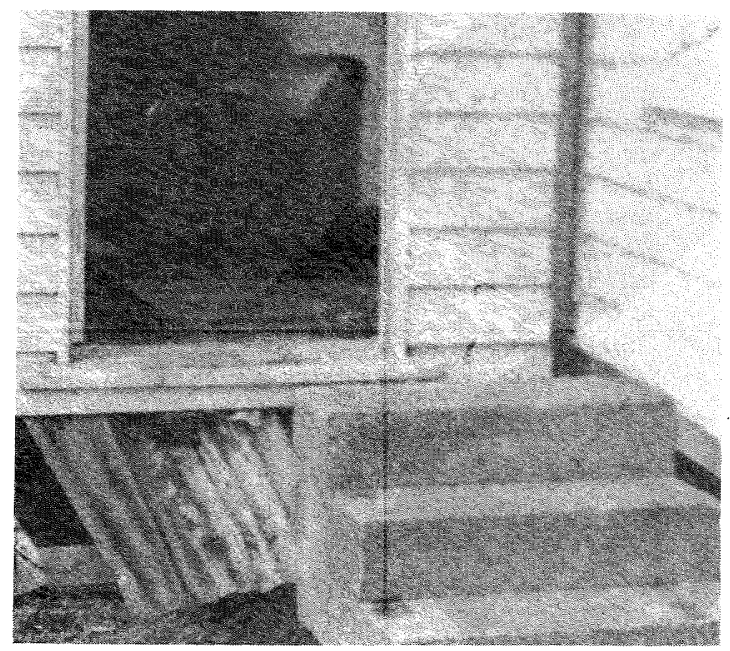

FIG 3: Inangahua earthquake: Typical example of lateral displacement of piled foundations. 


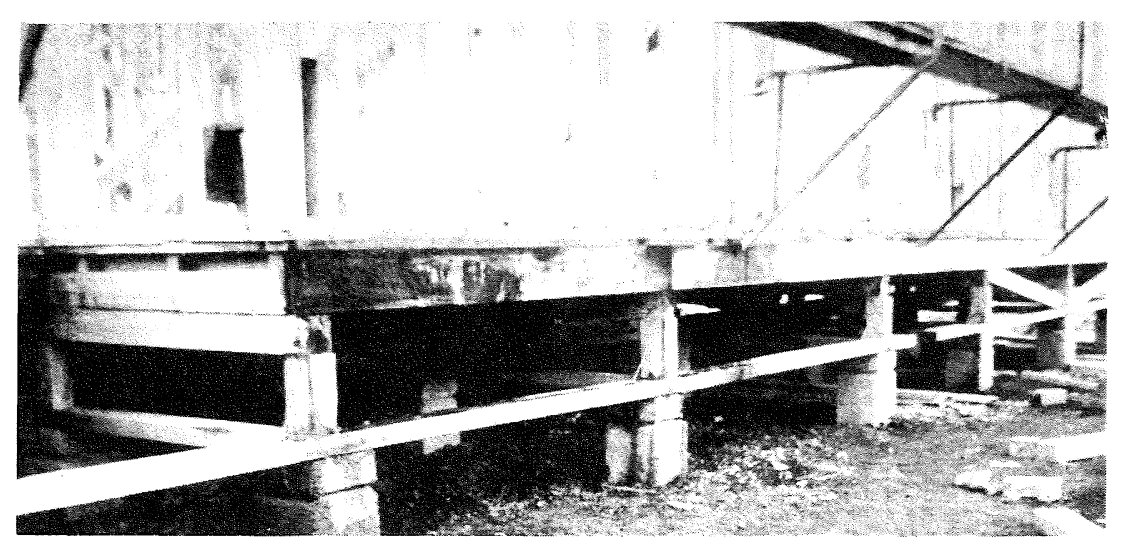

FIG 4: A 1970's subfloor support system virtually identical to those which collapsed at Napier in 1931

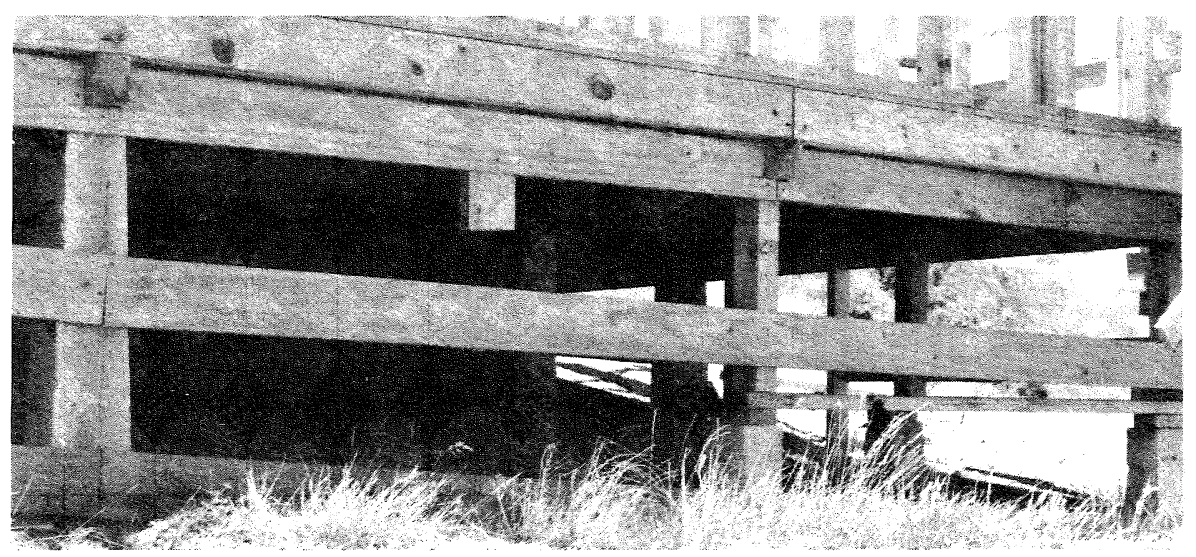

FIG 5: Subfloor support systems have often developed in response to gravity and frequently occurring wind loads (note packing between piles and jackstuds).

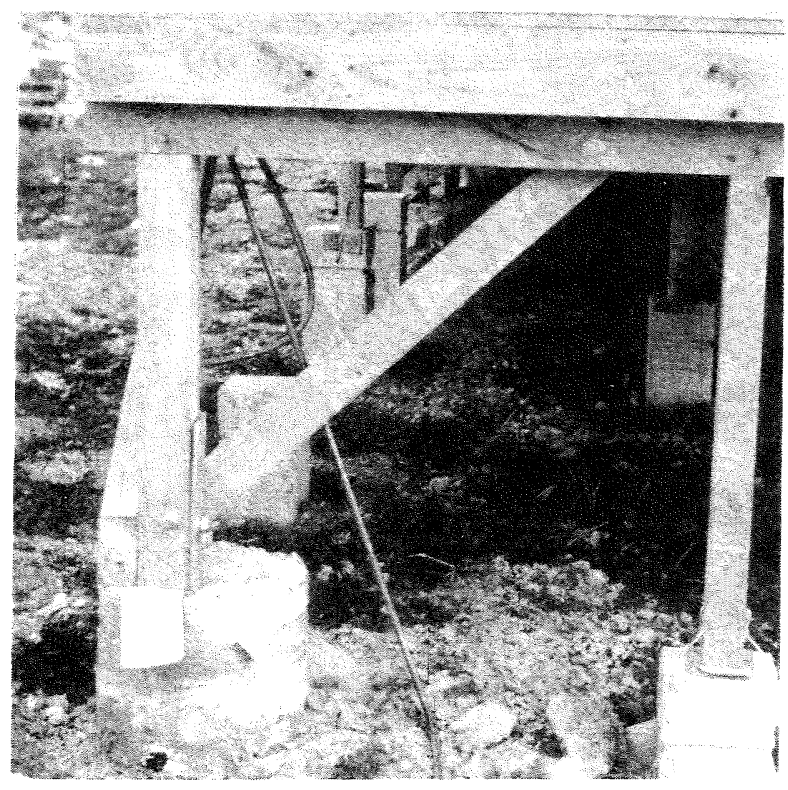

FIG 6: NZS 3604 specifically details diagonal subfloor braces bolted to an anchor pile as one method of providing lateral support 
sites timber jack studs are used to fill the gap betreen the foundations and the ground floor level. Around the perimeter the jack studs generally formed wall framing which is supported either on a bearer on top of piles or on a concrete foundation wall. Single jack studs were used with external piles and such construction was used to support both one and two storey houses. As previously mentioned bracing was usually confined to let-in or cut-between braces in perimeter walls and the inadequacy of this has been demonstrated in past earthquakes, as reported by Dixon(2) and Shepherd et al (5).

In spite of its obvious poor performance in earthquakes this form of construction has flourished and has been used extensively up until the present day. Actual details of construction have varied considerably throughout the country with the details being essentially decided by the carpenter on the site rather than compliance with any specification. Such constructions were seldom planned let alone specifically designed (Figs. 4 and 5). Support for gravity loads was obviously the main concern and sufficient diagonal braces were provided simply to stiffen the structure in order that no lateral movement could be felt during construction, and under every day service loads and frequently occurring wind loads. Braces to subfloor framing usually extended between the ground floor bearer level and the level of the tops of piles. Connection to the piles was by staple fixed wiring only. The resistance to overturning of the piles is simply provided by the bearing area of their footings. NZS 3604 (8) provides specific details for subfloor diagonal braces both in number and in location (Fig. 6).

One aspect of subfloor framing which resulted in poor performances in the past has been the degradation of timbers and fastenings due to inadequate subfloor ventilation. With the advent of preservative treated timbers this problem will no doubt be proved to be substantially reduced in future although in some cases the subfloor ventilation is still inadequate and degradation of fastenings can occur.

In the last couple of decades there has been a significant change in construction to provide for basement vehicle garaging under houses. This has commonly been achieved by supporting the house on a combination of posts, beams, foundation walls and wall framing (Figs. 7 and 9). Often the garages are not enclosed or when they are there is one wall which contains the garage doors. In a large number of such cases there has not been recourse to specific design. Posts and beams were apparently sized by rule of thumb from experience and bracing only provided if it was convenient to do so, or if the structure didn't feel "stiff" enough. certainly in many cases the braces and their fixings bear no relation to the loads they can be expected to carry. Often such houses are split level resulting in a discontinuity in the structure. Such split level houses incorporating garges are very similar in construction to those which had been developed in California and which were reported by Yanev(14) to have suffered severe damage in the San Fernando earthquake (Figs. 7 and 8 ).

None of these constructions in N.Z. have yet been subjected to even a moderate earthquake, however a number have been subjected to frequently occurring strong winds and have moved in the gusts to an extent that some additional bracing has been required to be fitted to reduce this movement.

NZS $3604^{(8)}$, in all but a few instances, specifically does not provide for such garages and basements under houses and hence engineering design of such construction is required.

\section{Wall Bracing}

Prior to the 1930's virtually all houses were lined internally with horizontal boarding, scrim, lining paper and wallpaper (Fig. 10). Such boarding was double nailed at each stud crossing and, whilst no mention of the effectiveness of this boarding on the bracing performance of walls appears to have been made, there is little doubt that it was in many cases considerable.

The degree to which the nail couples would be required to resist racking loads, and contribute to the equivalent viscous damping of the structure depends largely upon the manner in which the diagonal braces were fitted and the number of such braces in any particular wall. For $150 \times 25 \mathrm{~mm}$ braces checked partly into plates so as to have end bearing, the braces would be significantly more rigid when loaded in compression than the resistance provided by the boarding. For braces checked completely through plates, and for braces in tension, the rigidity is governed by the nails in shear which fixed the braces and in such cases the relative rigidity of the boarding would be considerably greater.

During the 1920's and 1930's first fibrous plaster sheets and then paper faced gypsum board sheets were introduced. The bracing effect that can be obtained from these sheets was not recognised or provided for in the standards bracing provisions up to and including NZSS $1900(12)$. Since the 1930's paper faced gypsum board became the predominant wall lining material with other wood-based materials being used increasingly in recent years.

During the same period diagonal braces were permitted to be reduced in size to $100 \times 25 \mathrm{~mm}$ in single storeys and then in practice gradually this size also crept into lower storeys in some areas. Also, as window sizes increased it became more difficult to provide braces in continuous lengths between top and bottom plates. Contrary to the intent of the regulations (which required that walls be "braced through their full height at an angle as near to $45^{\circ}$ as practicable" and that cut-between braces were required to be in 'continuous alignment'), 'dog-leg' or ' $\mathrm{K}$ ' braces were introduced and accepted in external walls. Often braces could not be provided at all (Fig.1). In more recent times the $100 \times 25 \mathrm{~mm}$ braces have been replaced with $22 \times 22 \times 1.2 \mathrm{~mm}$ cold formed galvanised steel angle braces. The bases for acceptance of this metal brace instead of the timber brace was that the overall racking performance of a typical $2.4 \mathrm{~m}$ square wall frame, both lined and unlined, was not substantially different, even though the metal angle brace itself had 


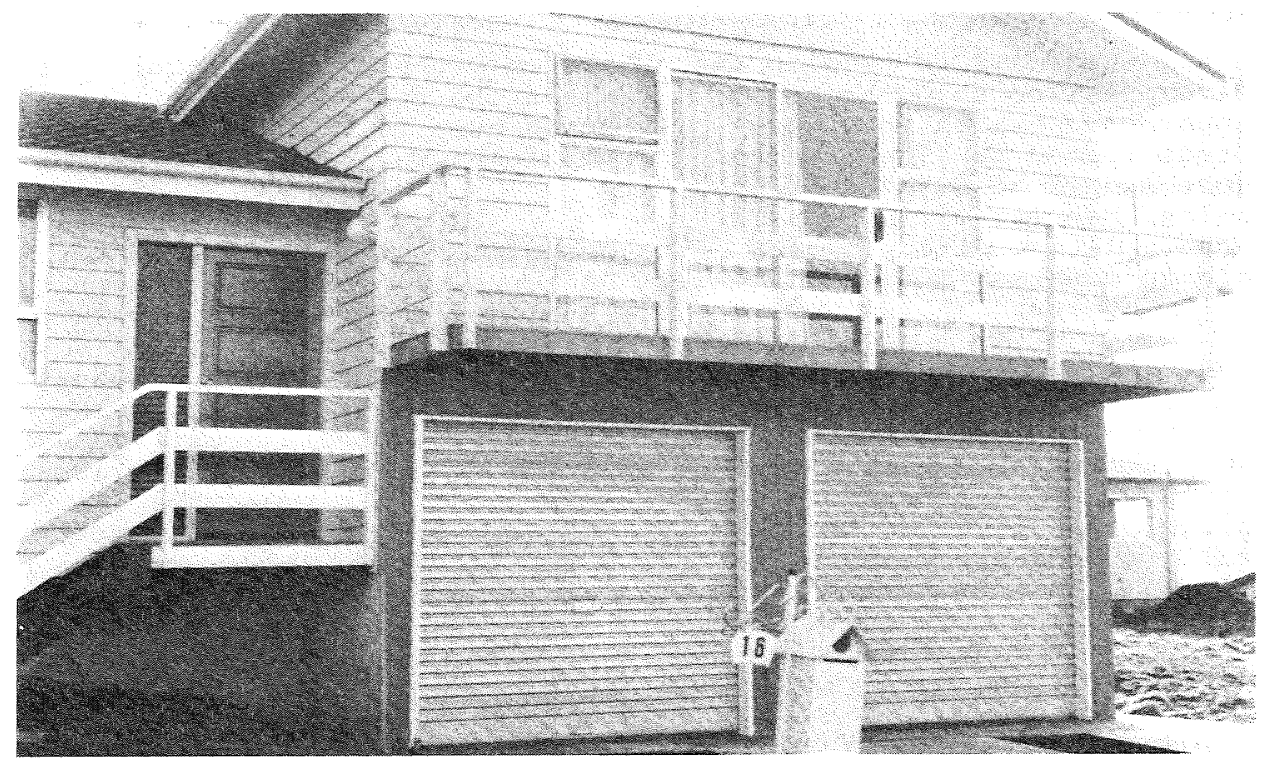

FIG 7: A house style of the 1960's and '70's; Split-level with enclosed basement garaging. (Compare with Fig. 8).

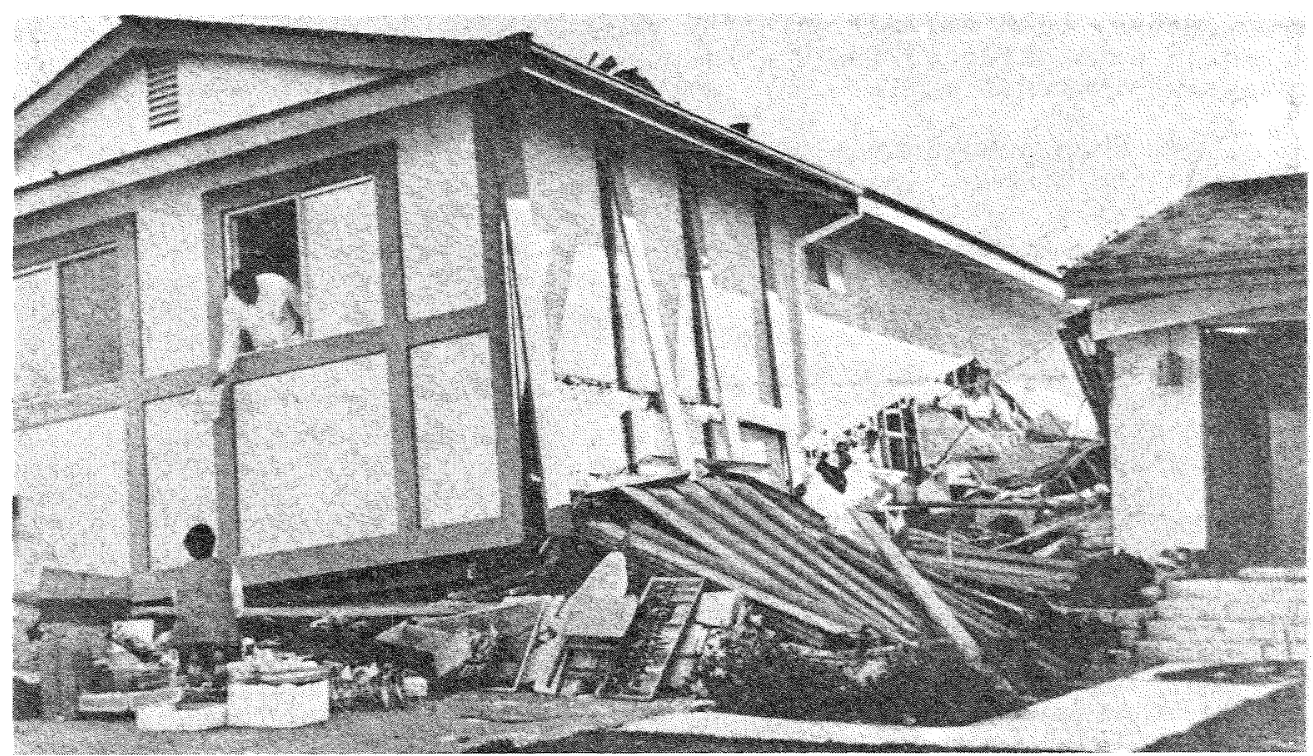

FIG 8: After the San Fernando earthquake of 1971: A similar construction to that depicted in Fig. 7. 
greater strength and stiffness in tension and less strength in compression than the timber brace. These comparative evaluations were carried out on studs spaced at $450 \mathrm{~mm}$ centres and when studs were spaced at $600 \mathrm{~mm}$ centres, for internal non-load bearing walls and some external walls, the relative effectiveness of the metal angle in compression was virtually unchallenged.

Testing conducted in recent years by the Forest Research Institute of the New Zealand Forest Service and the Building Research Association of New Zealand has established with more certainty the relative contributions that each of linings, claddings and braces make to the overall racking performance of timber frame walls and has established that nailed gypsum or wood based sheet linings well fixed with clouts contribute the greatest amount to the racking performance.

These results are significant in relegating the role of the diagonal brace to that of:

(a) holding the structure plumb during construction and resisting loads during construction:

(b) contributing a little to the bracing performance at working loads;

(c) contributing more in preventing collapse during earthquake events when the lining fixings may be $d$ igraded in strength and stiffness under cyclic loading.

They are more significant, however, in demonstrating that the move to ' $K$ ' or 'dog-leg' braces in particular was a retrograde move not so much as the effectiveness of the brace itself was concerned, although this has yet to be established, but rather it necessarily means that less sheet wall Iining is available to provide the majority of the racking resistance.

Internal walls, because there are generally more of them, play an equal if not greater role in resisting lateral loads. These walls have linings on both faces (initially boarding and then subsequently sheet materials) and hence the relative effectiveness of the diagonal brace compared with these linings was less than for external walls. However two significant changes have occurred in recent years, both virtually simultaneously, which have affected the racking performance of internal walls.

Framed roofs have been substantially replaced with trusses and hence where they are used few internal walls carry gravity loads. This allows for increased open Iiving space in houses and therefore more widely spaced internal walls, and it also allows for internal walls to be prefabricated off-site. This more open living space was naturally coupled with increased window areas and the use of floor to ceiling glass sliding doors opening to outdoor living areas. These houses possess substantially reduced torsional strength and stiffness compared with the older styled houses.

The prefabrication of internal walls led to panelized constructions (normally of stressed skin) being fixed to the floor decking and ceiling framing after the house was closed in. Such fixings have tended to be only the minimum required to locate and hold the panels in position, and seldom have been related to any bracing function that the walls may be required to serve.

NZS $3604^{(8)}$ requires that the total bracing requirements for each storey in a house be assessed relative to the expected earthquake forces, as governed by the building mass above that storey and the seismic zone. A number of differing types of wall constructions forming bracing elements, with given bracing performances, are provided for and these are to be distributed about the house in a prescribed manner. Floor, ceiling or roof diaphragms of sheet materials are allowed to play a role in this distribution process and can be effectively used to create larger rooms. The distribution of wall bracing elements is required to be as far as is practicable adjacent to external corners and also evenly distributed. However this cannot always be achieved, and whilst the bracing requirements are based on the assumption of uniform translation, torsional rotations will in practice occur resulting in increased loads to some elements. There is also provision for determining the bracing performance of new types of wall constructions by test(19) and prefabricated stressed skin internal wall panels and their fixings for instance fall into this category.

Diagonal braces used in conjunction with sheet lining materials are provided for with some restrictions. They can be of either metal angle, let-in $100 \times 25 \mathrm{~mm}$ timber, flat steel strip or cutbetween timber, the latter two being in diagonally opposed pairs. All diagonals must be in continuous straight alignment no steeper than $55^{\circ}$ to the horizontal. The significant point about these types of bracing elements now is that the bracing performance is based on the plan length of full height wall lining covering the brace and hence establishes this lining as a significant bracing component.

One of the advantages of using a large number of nails in shear for resisting earthquake forces is that large displacement ductilities are available to absorb the earthquake energy. Wall bracing elements, provided for in NZS 3604 either specifically or by test, must possess adequate displacement ductility, and this has been assessed as being four times the displacement at the code elastic design load. For houses, the deflection limit for the code design loads has been taken as being 1/300th of the wall height and hence the maximum displacement expected during the design earthquake for a house having the minimum bracing resistance required by the code is 1/75th of the wall height ( $32 \mathrm{~mm}$ for a standard $2.4 \mathrm{~m}$ high wal1). Increased loads on some elements through torsional effects will increase these displacements. Such displacements necessarily mean that plastic deformation, or in the case of gypsum materials brittle deformation, of the material on which these nail shanks bear, takes place, and hence the post earthquake stiffness is greatly reduced. This stiffness and the bracing strength can if necessary be fully restored after an earthquake by renailing the sheet material. 
In recent years panel construction with adhesive fixed sheet linings have been introduced for both internal and external walls. Such constructions necessarily depend upon the panel-to-structure fixings for strength and ductility and this has not always been provided.

\section{Masonry Veneers}

The methods of construction of contemporary masonry veneers are essentially similar to those damaged in earthquakes in recent decades and inspite of changes in masonry units, in mortars and in the fixings, one can expect similar performances of masonry veneers in future earthquakes.

The poor performance of masonry veneers in past earthquakes has been reported by Adams et al (4) and shepherd et al(5) (Fig. 11), the latter stating:

"The brick houses apparently shook as violently as the timber houses with the brick work being shattered at the corners and near the windows and doors.

One of the lessons to be learnt from the earthquake is that a rigid external sheathing cannot stiffen the flexible timber frame house since, with normal construction techniques, the brick veneer is not fastened to the timber frame except by wire ties that are not intended to be load carrying. Their purpose is merely to hold the brick work to the frame so as to prevent large sections falling and inflicting injury in an earthquake. At Inangahua, it seems that the flexible frame may have pulled the brick veneer with it, and could possibly have hit the brick work as it swayed. One way of avoiding this would be to provide a positive means of bracing the frame to the veneer such that the veneer could carry in-plane seismic forces without applying large face loads to the veneer panels. It may be practical to connect the top plate of the frame to the top of the brick veneer panel....... it seems however, quite illogical to use brittle and rigid unreinforced masonry veneers and chimneys in a structure with a very flexible supporting frame. The masonry components, in particular chimneys, besides sustaining damage to themselves, were responsible for a considerable amount of damage to the timber frame of the structure."

Whilst the problem of the incompatibility of rigid brittle masonry veneer used in conjunction with relatively flexible ductile timber framing has in the past been recognised, there has not been any attempt to change this situation and hence similar damage can be expected in future earthquakes. One can only assume that that substantially decreased maintenance cost, which is the principal reason for its popularity, has been somehow balanced against the risk of damage and hence cost of repair, and that damage is considered to be inevitable. This seems illogical though since these two costs are paid for by different parties; the home owner on the one hand the insurance agencies on the other and it is more likely that ignorance prevails.

If the wall frames are expected to rack up to approximately $32 \mathrm{~mm}$ at top plate level in order to dissipate the earthquake energy, then such displacements can only occur if if the masonry veneer and its fixings fail in two ways. First, the corners must separate with those veneer planes perpendicular to the direction of loading rotating about their base, and second, the veneer ties in walls parallel to the direction of loading must fail or deform or alternatively the veneer fail in shear, or a combination of these two failures occurs. In addition the wall framing to which the veneer is attached may undergo translation due to a flexible connection between it and the foundation wall on which the veneer rests. In particular laterally unsupported floor joists can rotate and increase this problem. Such translation will fail the veneer adjacent to the foundation wall on which it rests. At present the only requirement for veneer ties is that they must possess a prescribed minimum strength and stiffness in order to transfer face loads. This requirement, taken with the fact that there has been an increased use of building paper on the face of the studs and hence wire ties side fixed to the studs are no longer used, has resulted in the development of tie fixings which are also able to transfer significant shear loads in the olane of the wall between the veneer and the wall frame.

It is fortituous that gravity load considerations require that a masonry veneer be constructed on a continuous concrete foundation wall and in most cases the house structure is also supported on and attached to this wall. However it is not unknown for a house to be built on unbraced piles inside and separate from the foundation wall and damage in such instances can be expected to be considerably greater.

If damage to masonry veneers is to be reduced or eliminated then the veneer planes should be separated in some manner at all corners and veneer ties should not be capable of transferring in-plane shear loads to the wall frame. The latter could perhaps be achieved by providing a slotted hole for the tie to stud fixing. One other alternative is to detail a reinforced veneer which can resist the in-plane shear loads, however this does not seem to be realistic since, whilst details could be designed, it is unlikely that they will be properly achieved in practice. The demands for window openings effectively prevents the substantial stiffening of wall frames under racking loads which otherwise would be required.

The amount that masonry veneer either contributes to the overall lateral load on the supporting timber frame or assists in resisting such loads has not been evaluated, but will be very much dependent upon the particular geometric arrangement. One anomaly exists with respect of masonry veneer used with buildings which are specifically designed to be general structural design code NZS $4203(13)$. The separation provisions for brittle non-structural elements in that code would technically prevent masonry veneer from being used with specifically designed timber frame buildings which may be essentially identical in construction to non-designed light timber frame buildings.

Roof Framing Bracing

It has been mentioned that the only regulations requiring bracing of roof framing 


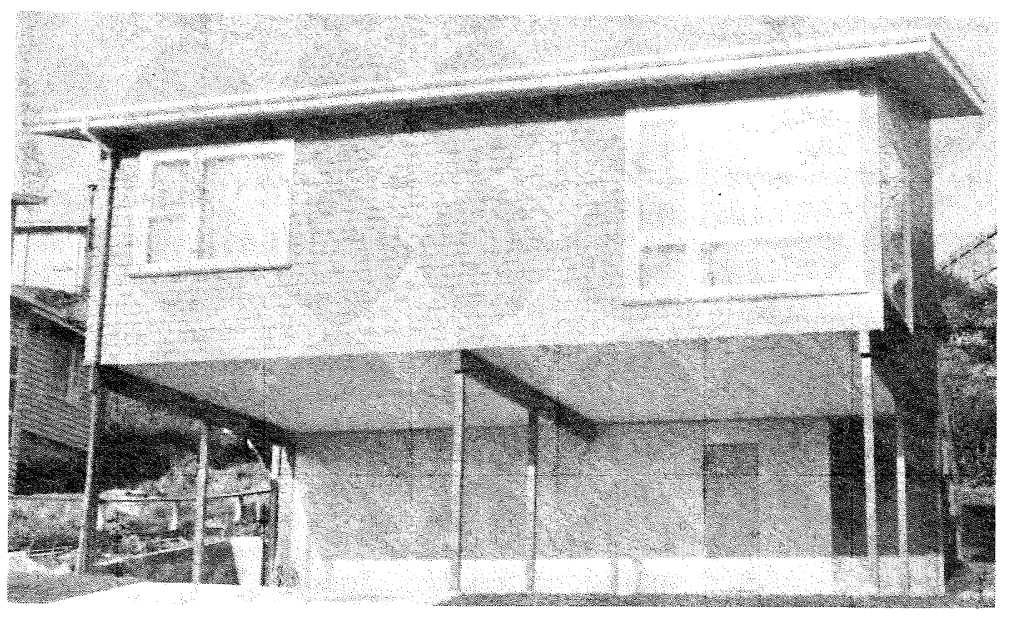

FIG. 9 Provision for basement car-parking without adequate consideration of earthquake loads. (Rear half of house obscured).

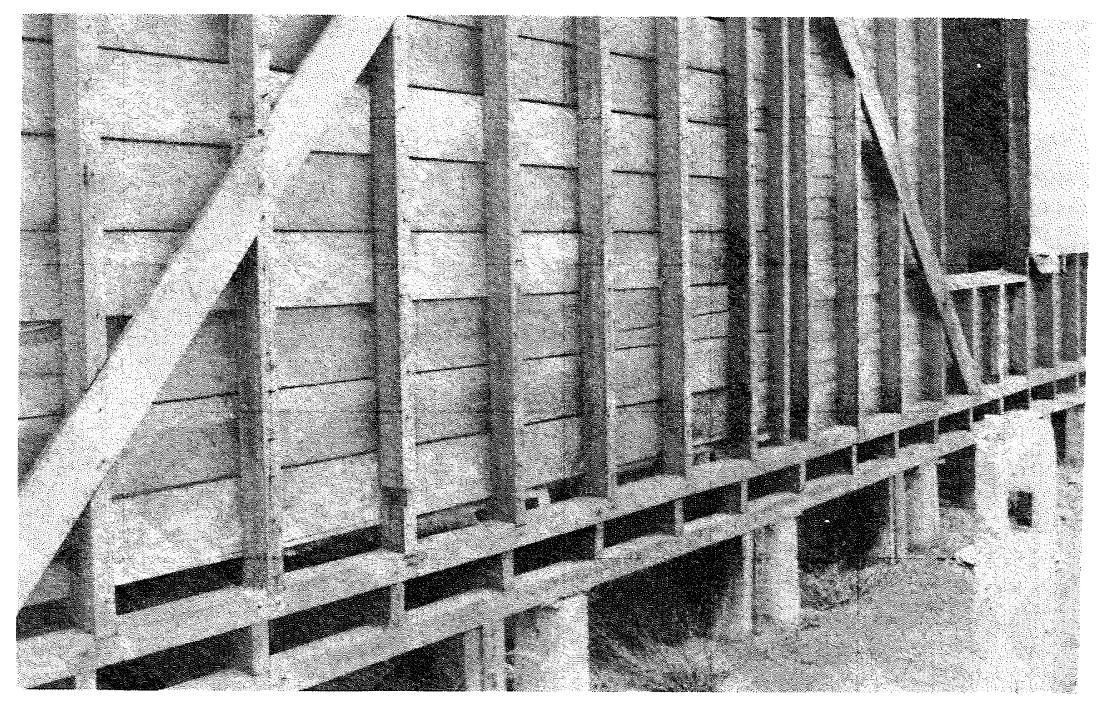

FIG 10: The 1920's: Internal boarding, substantial braces and relatively small proportion of wall openings (note repiling).

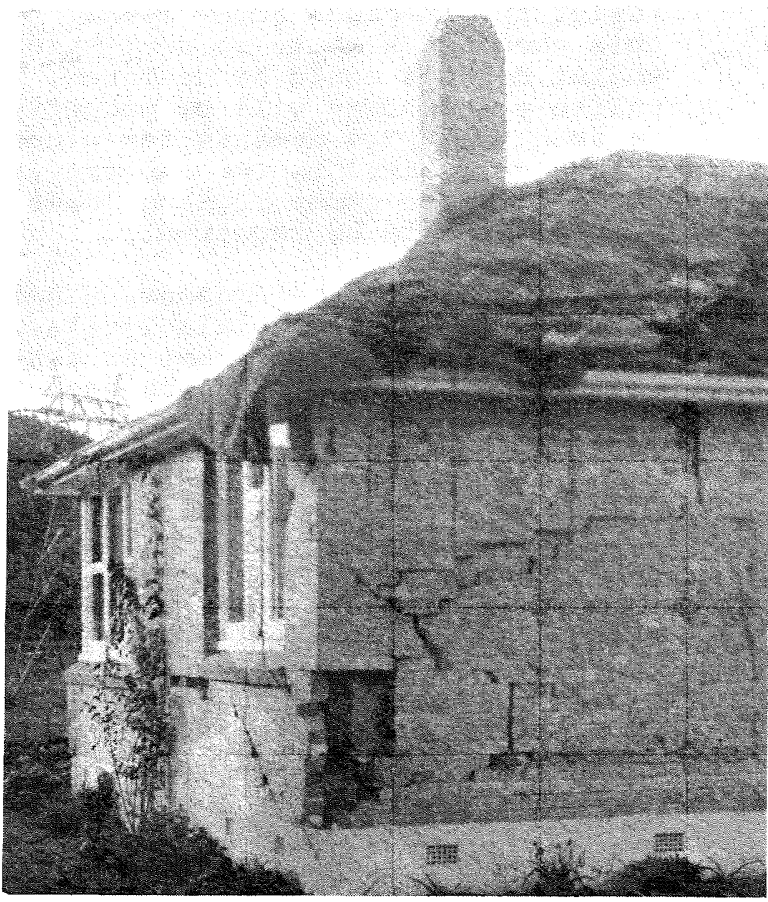

FIG 11: Inangahua earthquake: Brick veneer damage. Damage to concrete tiled roof covered by tarpaulin 
(including trusses) were in NZSS $95^{(10)}$ and even those depended upon sound trade practice based on experience.

Whilst prior to the $1930^{\prime} \mathrm{s}$ most roofs incorporated some hip or valley rafters, and hence some inherent bracing, in recent years there has been a significant move towards gable end roofs, especially since the introduction of roof trusses. Also, as architectural styles change periodically, roofs are often pitched up to $45^{\circ}$. Damage to gable end roofs with heavy tiles in the Inangahya, earthquake is mentioned by shepherd et al (5).

It appears that over recent years bracing of roof framing has been reduced to the minimum necessary to stiffen the roof framing during construction. NZS 3604 (8) specifically details roof framing bracing and the amount and type of bracing is related to the roof mass and type of roof construction. The bracing effect afforded by sheet roof claddings acting as a diaphragm is recognised, however such action has not yet been investigated sufficiently to allow for the deletion of diagonal braces where such cladding is used.

The poor performance of tiled roofs and their supporting structures and the injury potential of falling tiles is mentioned by both Eiby (20) and shepherd et al $(5)$.

State houses were at one stage required to have every tile fixed. However there is now a NZ standard, NZS $4206^{(21)}$ which covers the fixing of concrete roofing tiles. It appears that in preparing this standard little heed was taken of the advice given following previous earthquakes since not all tiles are required to be secured. Also, one method of fixing tiles, namely by wiring, has proven from experience in strong winds to be unsatisfactory due to corrosion of the wire after a number of years. Current practice is to nail, screw, or clip-fix tiles to resist wind uplift forces. However earthquake forces are not related to wind speeds; and also fixings designed to resist wind loads normal to the face of the tile may be ineffective in resisting earthquake loads in the plane of the tiles. As is the case with masonry veneers, concrete tiled roofs are popular because of their low maintenance.

\section{Chimneys}

\section{Eiby (20) says of chimneys:}

"There is little doubt that sentimental attachment to the open fire is responsible for the largest single earthquake hazard in the country.

It may be thought that the danger is limited to that of being hit by a falling brick. This is unfortunately not the case. Failure due to separation of the bricks is the greater hazard, but its operation is indirect...... If the chimney has a crack concealed behind the wood work the risk of fire is very great...... Records of the great San Francisco shock, and several more recent Japanese ones, show that the damage by fires lit after the earthquake was many times more costly than that caused by the shock itself."

In spite of the building bylaws for the construction of chimneys, non-earthquake resistant chimneys have been, and are being, constructed and rebuilt. The discontinuity of the reinforcement at the gathering, the lack of securement to the structure or alternatively self support, and the ineffective grouting of reinforcement, continued to be problem areas. This is amply illustrated by the reports of Hamilton et al (17) and Shepherd et al (5). Chimney and house constructions throughout the country are little different from those damaged at Gisborne and Inangahua and in future earthquakes we can expect similar damage.

A satisfactory solution to this chimney damage problem, both for the construction of new chimneys and the rebuilding of damaged ones, is not readily apparent. For instance, the provision of adequate separation between the chimney and the house structure and stability of the chimney structure, or alternatively the reinforcement and attachment of the chimney to the structure and the design of the structure to support the chimney, could be detailed and specified, particularly for single storey buildings. The additional costs and complexity of construction however may be such that the details would not be properly achieved in practice.

Some consolation can be gained from the fact that, because of factors such as cost and fuel shortages, relatively few new houses now have masonry chimneys. The extent of the problem will thus in time be proportionately reduced. However, the fact remains that at present a major proportion of the New Zealand housing stock have chimneys winich will be damaged or destroyed if subjected to severe earthquake forces. There also exists at present the strong possibility that they will be inadequately rebuilt after such an earthquake, as has happened previously.

\section{Services}

The loss of a main water supply is a real possibility in a severe earthquake. Typically, approximately 200 litres of water are stored in the hot water cylinder, and in many cases a header tank, in a house and hence the protection of this storage should be seriously considered. Work by Elkis(22) demonstrates that the securement of hot water cylinders can be achieved by means of simple mild steel straps. However, this will not be done in practice unless building bylaws require such fixing to be mandatory and to this end regulations are currently being drafted.

\section{THE FUTURE}

It is virtually inevitable that a number of houses which exist today will be subjected to a severe earthquake during their lifetime and hence, based on the performances of houses in past earthquakes, damage to many of these houses can be expected. Without the previous experience of an earthquake and without incentives, this situation will not be changed before such an event occurs since it requires expense and effort on the part of the home owner, whose attitude in any case is that the State will care since it is the state which provides the earthquake insurance.

It is important that an over-reaction with respect to house construction regulations should not happen after an earthquake disaster 
occurs. Damage to and destruction of many houses in a severe earthquake must be expected and treated accordingly. One significant factor which will help prevent such an overreaction will be if houses constructed in accordance with NZS $3604(8)$ are also subjected to the earthquake and they suffer comparatively little damage, with the exception of damage to masonry veneers and chimneys. In this respect the recent publication of NZS $3604(8)$ will hopefully prove to be timely.

The implementation in practice of all of the construction details in NZS $3604(8)$ cannot be guaranteed. Details required solely for earthquake resistance are not always specifically mentioned. In addition there is in any industry a reluctance to change if the reason is not obvious and the lack of recent earthquakes 'does not help'. The house building industry, and this includes designers, builders and inspectors, has in the past not demonstrated its ability to comply with all of the building bylaws and hence strong eduction and enforcement will be required if the new regulations contained in NZS $3604(8)$ are to be achieved.

The rehabilitation of older buildings is currently popular and indeed encouraged and in one area, namely piled foundations, the problem of lack of earthquake resistance is being perpetuated. In most instances wooden piles are simply being replaced with concrete ones without any lateral support being provided and unless regulations and construction details for earthquake resistance of these constructions are established, this same process will continue for some years yet since quite a number of older houses still have timber piles and these will eventually be replaced.

Considerable research into the performance of the various elements and the total house structure is still required in order to understand more fully its behaviour in earthquakes. The performance requirements for individual elements are also required in order that substitute elements of construction other than is covered by the light timber framing code, can be developed and evaluated, e.g. panelized internal non-load bearing walls used in conjunction with trussed roofs. The complex and integrated nature of the structure means that the performance of any particular element in isolation is in most instances not realistic and hence the best research models available will be houses in actual earthquakes. For this reason it is important that earthquake damage reporting systems for houses be properly established in order that maximum benefit can be gained. Even in moderate earthquakes where damage is slight, indications of the likely performance in severe earthquakes can be obtained.

It must however be recognised that whilst it is desirable to gain more information, sufficient technology exists at present to allow for the construction of houses which will adequately resist earthquake forces, but the application in practice of much of that technology is not yet being achieved, and this area must be improved in future.

\section{CONCLUSIONS}

1. The traditional $\mathrm{NZ}$ house constructed of light timber framing, clad with weather boards, having moderate window openings and haring a steel roof is a sound earthquake resistant structure. However, it is often founded on inadequate foundations.

2. Changes in materials and constructions resulting from technological developments and changes in architectural and living styles have often been incorporated into houses in isolation without adequate consideration of the overall structural behaviour of these structures in a severe earthquake. A significant number of house constructions contain weaknesses which have not yet become apparent because severe earthquakes only infrequently occur in populated areas of New Zealand. Some of these weaknesses :e:

(a) Inadequately braced pile foundations and subfloor framing. Damage can be expected to be severe with many such houses probably being uninhabitable having sever d service connections and distorted and damaged frames.

(b) Basement garages where provision for lateral support has not been specifically designed. As the San Fernando earthquake demonstrated, those which are split level risk the possibility of collapse and others will be severely damaged.

(c) Large areas of windows in external walls resulting in reduced and often inadequate wall areas capable of resisting racking loads.

(d) Non-load bearing internal walls, used in conjunction with trussed roofs, which may have been developed without due consideration of their racking performance.

(e) Insecurely fixed concrete and clay roofing tiles and inadequately braced roof framing supporting such tiles. Also inadequately braced structures in general when such heavy tiled roofs are used.

3. The inadequate performance of some houses and house components in past earthquakes has not always resulted in the development of building regulations which would reduce or prevent such damage reoccurring in future.

4. Masonry veneers as constructed to date are incompatible with light timber frame construction and can be expected to be damaged in moderate or severe earthquakes.

5. The poor performance of chimneys in past earthquakes demonstrates that they represent the greatest single source of damage and risk to life and limb in earthquakes.

6. Water storage facilities which could be used after an earthquake when main supplies are severed, have not been adequately protected against earthquake forces.

7. A new code of practice of light timber frame construction has recently been published and the provisions in this code are intended to rectify many of the deficiencies with respect to earthquake loadings which exist in many New Zealand house constructions. It is hoped that the current implementation of this code will prove timely in preventing an over-reaction when an earthquake disaster 
occurs.

\section{BIBLIOGRAPHY}

1. Grayland, E. C., "New Zealand Disasters". Wellington, Reed, 1957.

2. Dixon, C. E., "Earthquake Proves Superiority of Wooden Buildings", N.2. National Review, March 15, 1931: 45-58 and April 15, 1931: 45-61.

3. Brodie, A. and Harris, A. G., "Report of the Hawke's Bay Earthquake ( 3 February 1931)", Wellington, Govt. Print., 1933. (N.Z. Dept of Scientific and Industrial Research. Bulletin No 43.)

4. Adams, R. D. and others, "Seddon Earthquake, New Zealand, April 1966". Wellington, Govt. Print., 1970. (N.\&. Dept of Scientific and Industrial Research. Bulletin No 199.)

5. Shepherd, R. and others, "The 1968 Inangahua Earthquake". Canterbury Engineering Journal, No. 1, June 1970: $2-86$.

6. Housner, G. iv., and others, "Engineering Features of the San Fernando Earthquake February 9, 1971". Pasadena, Calif. California Institute of Technology Earthquake Engineering Research Laboratory, 1971. (Report No 71-02.)

7. Building Conference Relating to the Use of Timber in Building Construction. Wellington, Govt. Print., 1924. (NZ State Forest Service. Circular No 14.)

8. NZS 3604:1978. Code of Practice for Light Timber Frame Buildings Not Requiring Specific Design. Wellington, Standards Association of NZ.

9. ten Broeke, J., "Timber House Construction in New Zaland; a Survey of its Derformance". Auckland, Auckland Technical Institute, 1971. (Diploma in building case study).

10. NZSS 95. New Zealand Standard Code of Building By-laws. Wellington, Standards Association of $\mathrm{NZ}$. (Part IX-Light Timber Construction, Feb.1944; Part XII-Chimneys, July 1951.)

11. NZS 95-1936. New Zealand Standard Model Building By-law. Sections I-X. Wellington, Standards Association of New Zealand.

12. NZSS 1900:1964. New Zealand Standard Model Building By-law. Wellington, Standards Association of NZ. (Chapter 6-Construction requirements for buildings not requiring specific design, Division 6.1, TIMBER; Chapter 7 - Small chimneys and appliance installation.)

13. NZS 4203:1976. Code of Practice for General Structural Design and Design Loadings for Buildings. Wellington, Standards Association of NZ.

14. Yanev, P. "Peace of Mind in Earthquake Country; How to Save Your Home and Life". San Francisco, Chronicle Books, 1974.

15. "The South Island Earthquake of June 17 1929". Report of the NZ Institute of Architects Investigation Committee. Wellington, 1929.

16. Milne, D. S., "New Zealand Earthquakes: an Account in Storey and Pictures of Earthquakes, Their Effects, the Death and Destruction they have Caused, the Problems they Create". Auckland, Wilson and Horton, 1974

17. Hamilton, R. M. and others. "Gisborne Earthquake, New Zealand. March 1966." Wellington, Govt. Print., 1969. Dept of Scientific and Industrial
Research. Bulletin No 194.$)$

18. Private communication with Author.

19. Cooney, R. C. and Collins, M. J.

"A Wall Bracing Test and Evaluation Procedure". Wellington, Building Research Association of New Zealand, 1979. (Technical Paper P21).

20. Eiby, G. A., "Earthquakes". 2nd Ed. London, Frederick Muller, 1967.

21. NZS 4206:1973. Specification for Concrete Interlocking Roofing Tiles. Wellington, Standards Association of New Zealand.

22. Elkis, W. J., "A Hot Water Cylinder to Survive Earthquakes". New Zealand Journal of Science, 20, 1977: 265-71.

Paper received 27 July, 1979. A longer version of this paper was presented at the South Pacific Conference on Earthquake Engineering, Wellington, May 1979. 